\title{
PENERAPAN MODEL PEMBELAJARAN SCRAMBLE UNTUK MENINGKATKAN AKTIVITAS BELAJAR BIOLOGI SISWA DI KELAS XII IPA3 SMA NEGERI 1 PANYABUNGAN
}

\author{
Mardiana \\ Guru SMA Negeri 1 Panyabungan \\ Surel : mardiana@yahoo.co.id
}

\begin{abstract}
Abstrak
Penelitian ini bertujuan untuk melihat aktivitas belajar siswa dan hasil belajar siswa saat pemeblajaran pada mata pelajaran Biologi dengan model pembelajaran Scramble di kelas XII IPA3 SMA Negeri 1 Panyabungan. Data aktivitas siswa menurut pengamatan pengamat pada Siklus I antara lain: menulis/membaca (37\%), bekerja (20\%), bertanya sesama teman (15\%), bertanya kepada guru (14\%), dan yang tidak relevan dengan KBM (15\%). Data aktivitas siswa menurut pengamatan pada Siklus II antara lain menulis/membaca (29\%), bekerja (42\%), bertanya sesama teman (14\%), bertanya kepada guru (12\%), dan yang tidak relevan dengan KBM (15\%). Terjadi peningkatan aktivitas belajar biologi siswa saat menerapkan model pembelajaran scramble.
\end{abstract}

Kata Kunci : Model Pembelajaran Scramble, Hasil Belajar

\section{PENDAHULUAN}

$\begin{array}{llr}\text { Pendidikan } & \text { adalah } & \text { proses } \\ \text { pengembangan daya } & \text { nalar, } \\ \text { keterampilan, dan } & \text { moralitas }\end{array}$ kehidupan pada potensi yang dimiliki oleh setiap manusia. Suatu pendidikan dikatakan bermutu apabila proses pendidikan berlangsung secara efektif, manusia memperoleh pengalaman yang bermakna bagi dirinya dan produk pendidikan merupakan individuindividu yang bermanfaat bagi masyarakat dan pembangunan bangsa.

Berhasilnya tujuan pembelajaran ditentukan oleh banyak faktor diantaranya adalah faktor guru dalam melaksanakan proses belajar mengajar, karena guru secara langsung dapat mempengaruhi, membina dan meningkatkan kecerdasan serta keterampilan siswa. Untuk mengatasi permasalahan di atas dan guna mencapai tujuan pendidikan secara maksimal, peran guru sangat penting dan diharapkan guru memiliki cara/model mengajar yang baik dan mampu memilih model pembelajaran yang tepat dan sesuai dengan konsep-konsep mata pelajaran yang akan disampaikan.

Kondisi seperti ini terjadi dalam pembelajaran Biologi di SMA Negeri 1 Panyabungan. Dimana selama ini orientasi pembelajaran biologi masih pada bagaimana siswa memiliki sebanyak-banyaknya pengetahuan tentang biologi bukan menggali kaitan biologi dengan kehidupan. Dalam proses pembelajaran sering ditemukan bahwa pembelajaran masih berpusat 
pada guru. Siswa hanya sebagai pendengar sehingga siswa menjadi malas mengikuti pelajaran. Siswa menjadi tidak mandiri dan hanya mengandalkan teman yang pandai karena pembelajaran tidak difokuskan pada proses, namun pada hasilnya. Siswa akan melakukan perbuatan-perbuatan yang curang dalam mengerjakan tugas ataupun tes misalnya menyontek atau menjiplak. Hal tersebut terjadi akibat ketidakyakinan siswa pada kemampunnya sendiri. Pada akhirnya cara yang ditempuhpun tidak berhasil meski hanya sekedar mentrasfer pengetahuan. Hal ini karena pembelajaran menghafal sangat tidak disukai siswa, membuat siswa jenuh pada akhirnya menurunkan minat, aktivitas dan hasil belajar siswa.

Perlu dirumuskan suatu strategi baru dalam pembelajaran biologi. Strategi pembelajaran yang berpusat pada siswa, berorientasi pada pembentukan kecakapan hidup dari pada hanya sekedar memperoleh pengetahuan. Dalam proses pembelajaran yang menyangkut materi, metode, media alat peraga dan sebagainya harus juga mengalami perubahan kearah pembaharuan (inovasi). Dengan adanya inovasi tersebut di atas dituntut seorang guru untuk lebih kreatif dan inovatif, terutama dalam menentukan model dan metode yang tepat akan sangat menentukan keberhasilan siswa terutama pembentukan kecakapan hidup (life skill) siswa yang berpijak pada lingkungan sekitarnya.
Alternatif yang dapat dilakukan untuk mengatasi masalah dalam pembelajaran biologi diatas salah satunya dengan memberikan inovasi dalam pembelajaran berupa strategi yang mampu melibatkan siswa secara aktif, dapat memotivasi siswa, sebagai mediator, menciptakan suasana belajar mengajar yang baik dan menyenangkan sehingga mampu menggali kompetensi yang dimiliki oleh siswa untuk mencapai hasil belajar yang optimal. Salah satu model yang patut dicoba untuk menjawab masalah ini adalah model pembelajaran scramble. Model pembelajaran scramble bertujuan untuk melatih siswa dalam menguatkan pemahaman pembelajaran atau mengecek pemahaman siswa terhadap materi pembelajaran melalui bantuan lembar kerja yang berisi kata-kata yang diacak hurufnya. Model ini digunakan pada setiap mata pelajaran terutama yang mungkin mengembangkan sharing of information di antara siswa.

Kegiatan pembelajaran biologi dapat dilakukan melalui berbagai kegiatan seperti pengamatan, pengujian/penelitian, diskusi, penggalian informasi mandiri melalui tugas baca, wawancara nara sumber, simulasi/bermain peran, nyanyian, demonstrasi/peragaan model. Dengan semangat pembaruan maka peneliti terus mencobakan variasivariasi lain model pembelajaran 
berpusat pada siswa. Sehingga pada penelitian ini akan diterapkan model pembelajaran scramble.

Berdasarkan latar belakang masalah diatas, maka yang menjadi identifikasi masalah adalah sebagai berikut :

a. Pembelajaran yang seharusnya membentuk kecakapan hidup bukan sekedar menimbun pengetahuan

b. Pembelajaran biologi dengan menghafal menurunkan minat, aktivitas dan hasil belajar siswa.

c. Guru kurang maksimal dalam menggunakan model-model pembelajaran.

d. Keterbatasan perangkat dan sarana dalam pembelajaran biologi sebagai pemberian pengalaman langsung.

Karena keterbatasan peneliti dalam waktu dan biaya, maka penelitian dibatasi pada:

a. Menerapkan pembelajaran Scramble selama kegiatan pembelajaran biologi.

b. Subjek penelitian adalah siswa kelas XII IPA3 semester ganjil SMA Negeri 1 Panyabungan Tahun Pembelajaran 2014/2015.

c. Materi pokok yang diterapkan selama pengambilan data adalah teori tentang Prinsip hereditas d. Penelitin hanya dilaksanakan dalam dua siklus dengan dua pertemuan pembelajaran (KBM) setiap siklusnya.

Metode pemecahan masalah dalam penelitian ini yaitu dengan menerapkan model pembelajaran sramble. Dengan model pembelajaran ini diharapkan dapat meningkatkan aktivitas belajar siswa, dan hasil belajar siswa dalam pembelajaran biologi.

Untuk memperjelas masalah yang akan dibahas, maka yang menjadi rumusan masalah dalam penelitian ini adalah:

a. Bagaimana peningkatan aktivitas belajar biologi siswa saat bekerja dalam kelompok dengan menerapkan model pembelajaran scramble di kelas XII IPA3 SMA Negeri 1 Panyabungan?

b. Bagaimana peningkatan hasil belajar biologi siswa setelah menerapkan model Pembelajaran scramble di kelas XII IPA3 SMA Negeri 1 Panyabungan?

Setelah menetapkan rumusan masalah di atas maka, dapat ditentukan tujuan penelitian ini, antara lain;

a. Untuk mengetahui peningkatan aktivitas belajar biologi siswa saat bekerja dalam kelompok dengan menerapkan model pembelajaran scramble di 
kelas XII IPA3 SMA Negeri

1 Panyabungan.

b. Untuk

mengetahui

peningkatan hasil belajar biologi siswa setelah menerapkan model Pembelajaran scramble di kelas XII IPA3 SMA Negeri 1 Panyabungan.

Penelitian ini diharapkan dapat memberikan manfaat sebagai berikut:

a. Bagi siswa :

a) Siswa yang mengalami kesulitan dalam mengingat istilah yang sulit akan terkurangi bebannya.

b) Siswa lebih termotivasi untuk belajar.

c) Meningkatkan kemampuan bekerja sama dan bersosialisasi.

b. Bagi guru :

a) Mendapat Pengalaman langsung dalam pelaksanaan pembelajaran.

b) Sebagai motivasi meningkatkan

keterampilan untuk memilih strategi pembelajaran yang bervariasi yang dapat memperbaiki sistem pembelajaran sehingga memberikan layanan yang terbaik bagi peserta didik.
Guru dapat semakin menciptakan suasana lingkungan kelas yang menyenangkan tapi tetap serius.

\section{METODE PENELITIAN}

Tempat penelitian adalah tempat dimana penelitian ini dilakukan. Penelitian ini dilakukan di SMA Negeri 1 Panyabungan yang bertempat di Jalan J1 Suta Soripada Mulia Kecamatan Panyabungan Kabupaten Mandailing Natal.

Waktu penelitian adalah waktu berlangsungnya penelitian atau saat penelitian ini dilangsungkan. Penelitian ini dilaksanakan pada semester genap Tahun Pelajaran 2014/2015 selama 4 (empat) bulan mulai dari Agustus sampai dengan Nopember 2014. Pengambilan data dilaksanakan selama 4 (empat) KBM yang dibagi dalam 2 (dua) siklus pada Oktober 2014.

Subjek penelitian adalah siswasiswi kelas XII IPA3 SMA Negeri 1 Panyabungan Tahun Pelajaran 2014/2015 yang berjumlah 40 siswa.

Jenis penelitian ini adalah penelitian tindakan kelas (Classroom Action Research), meliputi 4 tahapan tiap siklusnya sebagai berikut : a). Perencanaan tindakan, b). Pelaksanaan tindakan, c). Observasi, d). Refleksi dan Evaluasi, (Arikunto dkk, 2009:16). Berikut ini adalah model penelitian tindakan kelas : 


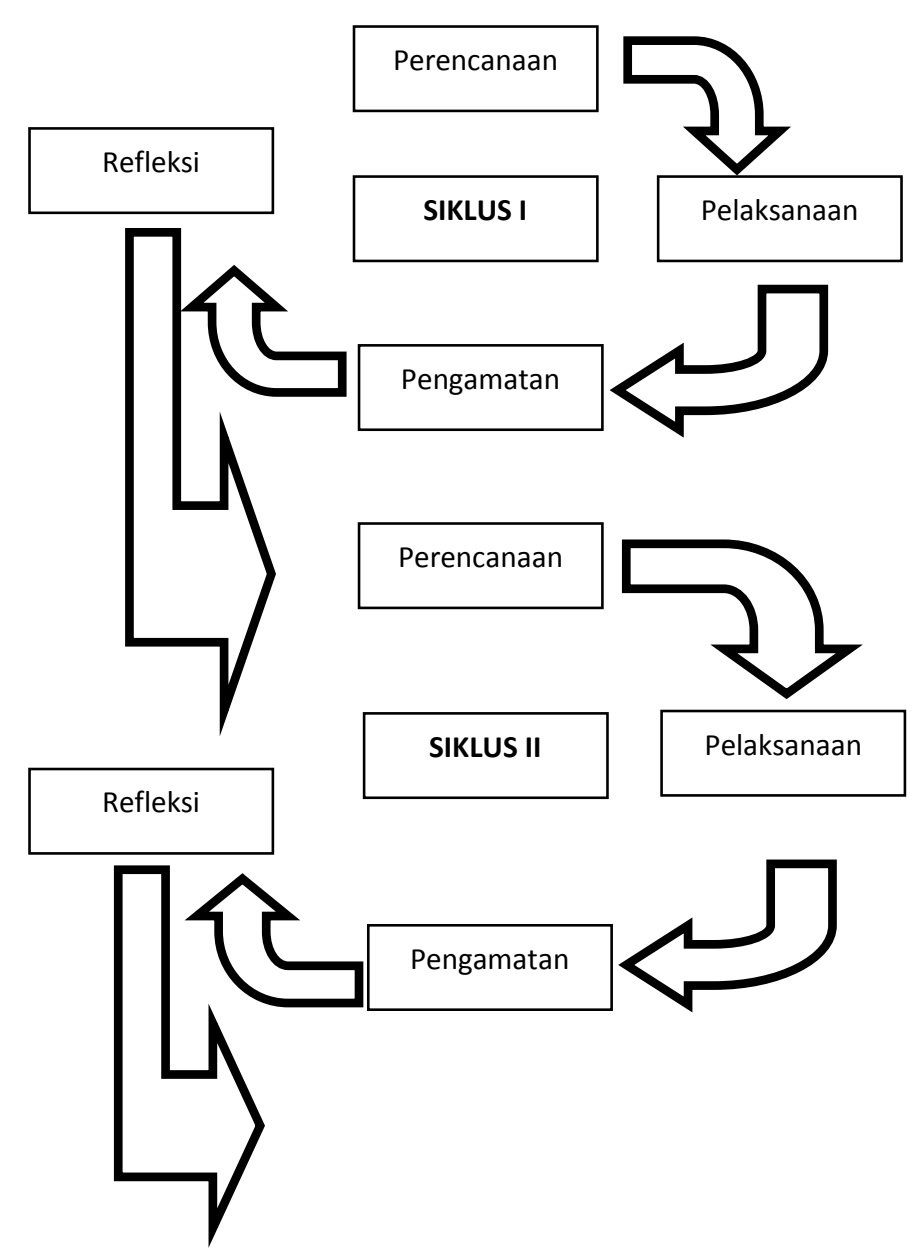

Gambar 3.1. Model Penelitian

Tindakan Kelas

Sesuai dengan jenis penelitian ini yaitu penelitian tindakan kelas, maka peneliti ini memiliki tahapan penelitian yang berupa satu siklus sebagai berikut :

a. Perencanaan

Adapun kegiatan yang

dilakukan dalam tahap perencanaan ini adalah:

a) Analisis Kurikulum

b) Memilih Model Pembelajaran yang sesuai dengan karakteristik siswa c) Menyusun Instrumen Tes hasil belajar

d) Menyusun RPP

e) Menyusun LKS

f) Menyusun Lembar Aktivitas belajar Siswa

g) Menyusun Lembar obeservasi tentang sikap selama siswa belajar dalam kelompok.

\section{b. Pelaksanaan Tindakan} Perbaikan Prosedur Penelitian Tindakan Kelas ini terdiri dari dua Siklus yaitu Siklus I dan Siklus II. Masingmasing Siklus menerapkan dua kali kegiatan belajar mengajar, sesuai dengan perubahan yang dicapai, seperti apa yang telah direncanakan dalam faktor yang diselidiki, untuk dapat melihat perubahan kemampuan siswa ddalam menyerap materi pembelajaran.

c. Observasi

Pada tahap ini observasi dilakukan saat bersamaan dengan tahap pelaksanaan tindakan. Pada tahap observasi ini, pengamat menggunakan lembar pedoman aktivitas dan lembar observasi. Pada tahap pelaksanaan tindakan ada 2 orang pengamat (guru) menggunakan Instrumen aktivitas belajar siswa, mengamati aktivitas siswa selama bekerja dalam kelompok. Ke dua pengamat dan peneliti sudah saling memahami cara-cara bagaimana menggunakan Instrumen yang diterapkan selama pengambilan data di kelas. Sampel yang diamati 1 kelompok per pengamat dan 
kelompok yang diamati ditentukan oleh peneliti sendiri tanpa sepengetahuan kelompok siswa. Setelah data terkumpukul baik data hasil belajar siswa, aktivitas belajar, dan hasil observasi selama kegiatan belajar mengajar, maka data tersebut dianalisis, sehingga dapat diketahui karakter siswa tentang pemahaman materi pembelajar, dan sikap siswa selama bekerja perindividu atau berkelompok.

\section{d. Refleksi}

Tahap ini dilakukan untuk menganalisa dan memberi arti terhadap data yang diperoleh memperjelas data yang diperoleh sehingga diambil kesimpulan dari tindakan yang telah dilakukan. Hasil refleksi ini kemudian digunakan sebagai dasar untuk perencanaan pada Siklus berikutnya.

Instrumen yang digunakan dalam penelitian ini terdiri dari:

\section{a. Rencana Pelaksanaan Pelajaran (RPP) \\ Yaitu merupakan perangkat} pembelajaran yang digunakan sebagai pedoman guru dalam mengajar dan disusun untuk tiap putaran. Masing-masing RRP berisi kompetensi dasar, indikator pencapaian hasil belajar, tujuan pembelajaran khusus, dan kegiatan belajar mengajar.

\section{b. Lembar Kegiatan Siswa}

Lembar kegiatan siswa ini yang dipergunakan siswa untuk membantu proses pembelajaran dan mengarahkan aktivitas siswa dalam pembelajaran.

c. Lembar Observasi Aktivitas Siswa

Lembar observasi aktivitas siswa untuk mengamati aktivitas siswa selama berdiskusi kelompok. Lembar ini digunakan oleh dua pengamat. Ke dua pengamat tersebut mengamati masing-masing satu kelompok setiap satu KBM yang sudah ditentukan oleh peneliti/guru. Pengamat tidak boleh duduk bersamaan untuk menghindari data bias. Pengamat mentabulasi data/menceklis pada lembar aktivitas ini selama dua menit sekali. Sebagai contoh, bila kerja kelompok ditentukan oleh peneliti selama 20 menit maka pengisian data pada lembar aktivitas jumlah per siswa ada 10 ceklis. 10 ceklis ini posisinya pada 5 aktivitas ini sesuai dengan pengamatan. Setelah data terkumpul, maka data tersebut dianalisis sehingga setiap aktivitas dapat ditentukan persentasenya. Observasi aktivitas akan di konfirmasikan dengan data dokumentasi penelitian berupa foto penelitian.

d. Tes formatif

Tes ini disusun berdasarkan tujuan pembelajaran yang akan dicapai. Bentuk soal yang diberikan adalah soal essay. Tes formatif ini berjumlah seluruhnya 9 soal. Tes formatif ini digunakan untuk mengetahui kemampuan awal (pretes) dan kemampuan akhir siswa. Setelah kegiatan belajar mengajar dilaksanakan (Siklus I), maka dilakukan tes formatif disebut 
formatif I dengan jumlah 5 soal. Akhir KBM pada Siklus II, dilakukan tes formatif terakhir atau disebut formatif II dengan jumlah 4 soal, dan soalnya diambil dari soal pretes sesuai dengan materi pembelajaran. Tes formatif ini sesuai klasifikasi/kisi-kisi tes dan dapat dilihat pada Tabel 3.1.

Tabel 3.1 : Tabel Kisi-Kisi Tes Hasil Belajar

\begin{tabular}{|c|c|c|c|c|c|}
\hline \multirow{2}{*}{ No. Soal } & \multicolumn{4}{|c|}{ Klasifikasi / Kategori } & Jumlah \\
\hline & $\mathrm{C}_{2}$ & $\mathrm{C}_{3}$ & $\mathrm{C}_{4}$ & $\mathrm{C}_{5}$ & soal \\
\hline 01. & $\mathrm{~V}$ & & & & 1 \\
\hline 02. & & $\mathrm{~V}$ & & & 1 \\
\hline 03. & & $\mathrm{~V}$ & & & 1 \\
\hline 04. & & & & $\mathrm{~V}$ & 1 \\
\hline 05. & & & $\mathrm{~V}$ & & 1 \\
\hline 06. & & & $\mathrm{~V}$ & & 1 \\
\hline 07. & & & & $\mathrm{~V}$ & 1 \\
\hline 08. & & & $\mathrm{~V}$ & & 1 \\
\hline 09. & & $\mathrm{~V}$ & & & 1 \\
\hline Jumlah & 1 & 3 & 3 & 2 & 9 \\
\hline
\end{tabular}

Keterangan :

$\mathrm{C}_{2}$ : Pemahaman

$$
\mathrm{C}_{4} \text { : Analisis }
$$

$\mathrm{C}_{3}$ : Aplikasi

$C_{5}$ : Sintesis diperoleh dengan tujuan untuk mengetahui prestasi belajar yang dicapai siswa juga untuk memperoleh respon siswa terhadap kegiatan pembelajaran serta aktivitas siswa selama proses pembelajaran.

Untuk mengalisis tingkat keberhasilan atau persentase keberhasilan siswa setelah proses belajar mengajar setiap putarannya dilakukan dengan cara memberikan evaluasi berupa soal tes tertulis pada setiap akhir siklus.

Analisis ini aktivitas dan hasil formatif dihitung dengan menggunakan statistik sederhana yaitu:

a. Untuk penilaian aktivitas digunakan rumus sebagai berikut:

\% Proporsi Aktivitas

$=\frac{\text { jumlah skor yang diperoleh }}{\text { jumlah skor ideal }} \times 100 \%$

(Majid, 2009:268)

Hasil penilaian aktivitas dibandingkan setiap siklusnya untuk memperoleh gambaran apakah terjadi perbaikan aktivitas belajar siswa.

\section{Teknik Analisis Data}

Untuk mengetahui keefektivan suatu model dalam kegiatan pembelajaran perlu diadakan analisa data. Pada penelitian ini menggunakan teknik analisis deskriptif kualitatif, yaitu suatu metode penelitian yang bersifat menggambarkan kenyataan atau fakta sesuai dengan data yang b. Untuk menilai ulangan atau tes formatif

Peneliti melakukan

penjumlahan nilai yang diperoleh siswa, yang selanjutnya dibagi dengan jumlah siswa yang ada di kelas tersebut sehingga diperoleh rata-rata tes formatif dapat dirumuskan: 


$$
\bar{X}=\frac{\sum X}{\sum N}
$$

Dengan $: \bar{X} \quad=$ Nilai rata-rata

$$
\Sigma X=
$$

Jumlah semua nilai siswa

$$
\Sigma \mathrm{N}=
$$

Jumlah siswa

c. Untuk ketuntasan belajar

Ada dua kategori ketuntasan belajar yaitu secara perorangan dan secara klasikal. Untuk ketuntasan perorangan maka digunakan KKM SMA Negeri 1 Panyabungan untuk mata pelajaran biologi kelas XII yakni 75. Berdasarkan petunjuk pelaksanaan belajar mengajar kurikulum 1994 (Depdikbud, 1994), kelas disebut tuntas belajar bila di kelas tersebut terdapat paling tidak $85 \%$ siswa yang telah mencapai daya serap $\geq$ KKM. Untuk menghitung persentase ketuntasan belajar digunakan rumus sebagai berikut:

$$
P=\frac{\sum \text { Siswa.yang.tuntasbelajar }}{\sum \text { Siswa }} \times 100 \%
$$

Yang menjadi indikator keberhasilan guru mengajar digunakan Kurikulum KTSP atau kriteria ketuntasan minimal (KKM) di sekolah untuk mata pelajaran biologi adalah 75 . Jika nilai $\geq 75$ siswa tuntas secara individu. Jika nilai $\geq 75$ diperoleh $\geq 85 \%$ dikatakan tuntas secara klasikal/tuntas kelas.

\section{HASIL PENELITIAN DAN PEMBAHASAN \\ Data penelitian yang} diperoleh berupa data observasi pengamatan pengelolaan model pengajaram scramble dan pengamatan aktivitas siswa, dan data tes hasil belajar siswa pada setiap siklus. Data lembar observasi diambil dari dua pengamatan yaitu data pengamatan pengelolaan model pengajaran scramble yang digunakan untuk mengetahui pengaruh penerapan model pengajaran scramble dalam meningkatkan hasil belajar siswa dan data pengamatan aktivitas siswa serta data pengamatan minat siswa dalam mengikuti kegiatan belajar mengajar.

Data tes hasil belajar untuk mengetahui peningkatan prestasi belajar siswa setelah diterapkan proses belajar mengajar dengan menerapkan model pengajaran scramble. Sebelum dilakuakn KMB Siklus I dilakukan tes hasil belajar sebagai tes kemampuan awal siswa. Merujuk pada lampiran data Pretes diperoleh nilai terendah siswa 25,0, sedangkan nilai tertingginya 78,1 . Dengan rata-rata 46,9 , sedangkan KKM adalah 75 maka, lima seorang siswa memperoleh nilai tuntas atau ketuntasan klasikal 13,00 \%. Dapat dipahami karena memang siswa belum diajarkan materi ini, akan tetapi rendahnya kemampuan awal menggambarkan bahwa siswa belum mempersiapkan diri sebelumnya dari rumah. 


\section{Siklus I}

\section{a. Tahap Perencanaan}

Pada tahap ini peneliti mempersiapkan perangkat pembelajaran yang terdiri dari rencana pelaksanaan pembelajaran 1 dan 2, LKS 1 dan 2, soal tes formatif 1, lembar observasi aktivitas siswa dan alat-alat pengajaran yang mendukung.

\section{b. Tahap kegiatan dan pelaksanaan}

Pelaksanaan kegiatan belajar mengajar untuk Siklus I dilaksanakan utuk KBM 1 pada Kamis tanggal 16 Oktober 2014 pada jam pelajaran ke5 dan ke-6 di kelas XII IPA3 dengan diikuti 40 siswa. Sub materi pokok yang dibahas adalah hukum mendel dan model perkawinan. Sementara KBM 2 pada senin tanggal 20 Oktober 2014 pada jam pelajaran ke3 dan ke-4 dengan diikuti 40 siswa. sub materi pokok yang dibahas adalah hukum mendel dan model perkawinan. Dalam seluruh kegiatan pembelajaran ini, peneliti bertindak sebagai guru.

\section{Adapun proses belajar} mengajar mengacu pada rencana pelaksanaan pembelajaran yang telah dipersiapkan. Pengamatan (observasi) dilaksanakan bersamaan dengan pelaksanaan belajar mengajar ketika fase diskusi kelompok mengenai data hasil pengamatan dalam praktikum. Selama kegiatan pembelajaran pemungutan data dokumentasi foto penelitian juga dilakukan.

\section{c. Tahap Observasi}

Data aktivitas belajar siswa

Pada tahap observasi peneliti melakukan pengamatan selama kegiatan berlangsung dengan bantuan dua orang guru untuk mengamati kegiatan siswa selama proses pembelajaran berlangsung dengan menggunakan lembar observasi aktifitas siswa.

Dari hasil pengamatan aktivitas siswa diperoleh data aktivitas yang disajikan dalam Tabel 4.1.

Tabel 4.1 Skor Aktivitas Belajar Siswa Siklus I

\begin{tabular}{|c|l|c|c|c|}
\hline \multicolumn{5}{|c|}{ Siklus I } \\
\hline No & \multicolumn{1}{|c|}{ Aktivitas } & Jumlah & Skor & Persentasi \\
\hline 1 & Menulis,membaca & 74 & 18,5 & $37 \%$ \\
\hline 2 & $\begin{array}{l}\text { Mengerjakan } \\
\text { Bertanya pada } \\
\text { teman }\end{array}$ & 29 & 70,25 & $15 \%$ \\
\hline 4 & $\begin{array}{l}\text { Bertanya pada } \\
\text { guru }\end{array}$ & 28 & 7 & $14 \%$ \\
\hline 5 & $\begin{array}{l}\text { Yang tidak relevan } \\
\text { Jumlah }\end{array}$ & 29 & 7,25 & $15 \%$ \\
\hline
\end{tabular}

\section{Data Hasil Belajar Siswa}

Pada akhir proses belajar mengajar siswa diberi tes formatif I dimana soalnya adalah bagian dari pretes yang indikatornya telah dipelajari sebelumnya pada Siklus I. Tujuannya adalah untuk mengetahui tingkat keberhasilan siswa dalam proses belajar mengajar yang telah dilakukan. Adapun data hasil 
penelitian pada Siklus I disajikan dalam Tabel 4.2.

Tabel 4.2 Distribusi Hasil Formatif I

\begin{tabular}{|c|c|c|c|c|}
\hline Nilai & Frekuensi & $\begin{array}{l}\text { Rata- } \\
\text { Rata }\end{array}$ & S. Deviasi & K Klasikal \\
\cline { 1 - 2 } $50-59$ & 16 & & & \\
\cline { 1 - 2 } $60-69$ & 2 & \multirow{2}{*}{74,38} & \multirow{2}{*}{22,01} & \multirow{2}{*}{$55,00 \%$} \\
\cline { 1 - 2 } $70-79$ & 3 & & \\
\cline { 1 - 2 } $80-89$ & 6 & & & \\
\cline { 1 - 2 } 100 & 13 & & & \\
\hline Jumlah & 40 & &
\end{tabular}

Pada hasil belajar sikls I nilai terendah Formatif I adalah 50 sebanyak 16 orang dan nilai tertinggi adalah 100 sebanyak 13 orang, ketuntasan klasikal adalah sebesar $55,00 \%$. Dengan nilai KMM sebesar 75 , nilai ini berada di bawah kriteria keberhasilan klasikal sehingga dapat dikatakan KBM Siklus I kurang berhasil memberi ketuntasan belajar dalam kelas. Nilai rata-rata kelas adalah 74,38 belum mencapai nilai batas KKM Biologi.

\section{d. Refleksi dan Revisi Siklus I}

Berdasarkan hasil observasi, dokumentasi penelitian dan hasil formatif serta interpretasi tindakan pada Siklus I, peneliti melakukan analisis kelemahan dalam Siklus 1, sehingga diperoleh diantaranya :

a) Guru kurang maksimal dalam memotivasi siswa dan dalam menyampaikan

tujuan pembelajaran

b) Siswa belum focus melaksanakan diskusi karena banyak yang bingung dan tidak ada pemikiran untuk didiskusikan.

c) Pemanfaatan LKS yang belum begitu optimal dalam mengarahkan aktivitas belajar siswa.

d) Beberapa siswa belum memahami peran dan tugasnya dalam bekerja kelompok karena belum terbiasa dengan model pembelajaran yang diterapkan hal ini menyebabkan muculnya aktivitas individual menulis dan membaca (37\%) sebagai akibat siswa tidak mengerti apa yang harus dikerjakan.

e) Interaksi antar siswa belum berjalan dengan baik karena siswa belum terbiasa untuk menyampaikan pendapatnya kepada sesama teman lainnya dalam menyelesaikan masalah.

f) Adanya siswa yang pasif dan menggantungkan

permasalahan yang dihadapi kepada kelompoknya mengakibatkan aktivitas kinerja belum optimal (20\%).

g) Dalam diskusi kelompok hanya didominasi oleh beberapa siswa yang lebih mampu/pandai saja terlihat aktivitas tidak relevan oleh 
beberapa siswa (15\%) dan dari dokumentasi penelitian.

Dari refleksi pada siklus I, maka perlu dilakukan revisi untuk perbaikan pada Siklus II, yaitu :

a) Guru perlu lebih terampil dalam memotivasi siswa dan lebih jelas dalam menyampaikan tujuan pembelajaran. Dimana siswa diajak untuk terlibat langsung dalam setiap kegiatan yang akan dilakukan.

b) Menampilkan media chart untuk membantu siswa memunculkan pemikiran untuk didiskusikan.

c) Guru mengoptimalkan penggunaan LKS agar siswa lebih paham tentang alur pembelajaran yang harus dilakukan sehingga aktivitas belajarnya terarah.

d) Guru harus lebih membangkitkan minat dan perhatian siswa pada materi yang disampaikan.

e) Guru harus bisa memanajemen waktu sebaikbaiknya agar kegiatan belajar mengajar bisa berjalan lancar.

f) Guru lebih memotivasi siswa dengan cara pemberian pujian dan penghargaan.

g) Guru mengkoordinasi pembagian tugas secara spesifik.

h) Guru harus bisa menyampaikan materi dengan lebih jelas lagi agar siswa dapat lebih mudah memahami materi yang disampaikan.

\section{Siklus II}

\section{Tahap perencanaan}

Pada tahap ini peneliti mempersiapkan perangkat pembelajaran yang terdiri dari rencana pelaksanaan pembelajaran 3 dan 4, LKS 3 dan 4, lembar observasi aktivitas siswa, soal tes formatif II, dan alat-alat pengajaran yang mendukung. Selain itu dengan mempertimbangkan refleksi dan revisi Siklus I maka semua perangkat disusun dengan mempertimbangkan tindakan perbaikan yang akan dilakukan sehingga selaras dengan perencanaannya.

\section{Tahap kegiatan dan pelaksanaan}

Pelaksanaan kegiatan belajar mengajar untuk Siklus II dilaksanakan utuk KBM 3 pada Kamis tanggal 23 Oktober 2014 pada jam pelajaran ke-5 dan ke-6 di kelas XII IPA3 dengan diikuti 40 siswa. Sub materi pokok yang dibahas adalah Menerapkan beberapa pola penurunan sifat. Sementara KBM II pada Senin tanggal 27 Oktober 2014 pada jam pelajaran ke-3 dan ke-4 dengan diikuti 40 siswa. sub materi pokok yang dibahas adalah Menerapkan pola-pola hereditas pada manusia. Dalam seluruh kegiatan pembelajaran ini, peneliti bertindak sebagai guru.

Adapun proses belajar mengajar mengacu pada rencana pelaksanaan pembelajaran yang telah dipersiapkan. Pengamatan (observasi) dilaksanakan bersamaan dengan pelaksanaan belajar mengajar 
ketika fase diskusi kelompok mengenai data hasil diskusi. Selama kegiatan pembelajaran pemungutan data dokumentasi foto penelitian juga dilakukan.

\section{Tahap Observasi}

Data aktivitas belajar siswa Pengamatan terhadap aktivitas belajar siswa (observasi) dilakukan selama kegiatan diskusi kelompok yang berlangsung selama 20 menit oleh dua pengamat yang setelah ditabulasikan untuk Siklus I selama dua KBM disajikan dalam Tabel 4.3.

Tabel 4.3 Skor Aktivitas Belajar Siswa Siklus II

\begin{tabular}{|c|c|c|c|c|}
\hline \multicolumn{5}{|c|}{ Siklus I } \\
\hline No & Aktivitas & Jumlah & Skor & Persentasi \\
\hline 1 & Menulis,membaca & 57 & 14,25 & $29 \%$ \\
\hline 2 & Mengerjakan & 84 & 21 & $42 \%$ \\
\hline 3 & $\begin{array}{l}\text { Bertanya pada } \\
\text { teman }\end{array}$ & 27 & 6,75 & $14 \%$ \\
\hline 4 & $\begin{array}{l}\text { Bertanya pada } \\
\text { guru }\end{array}$ & 23 & 5,75 & $12 \%$ \\
\hline 5 & Yang tidak relevan & 9 & 2,25 & $5 \%$ \\
\hline & Jumlah & 200 & 50 & $100 \%$ \\
\hline
\end{tabular}

Aktivitas membaca dan menulis sudah turun menjadi $29 \%$ dari $37 \%$ pada Siklus I, Hal ini menunjukkan siswa mulai terarah aktivitasnya melalui bantuian LKS. Aktivitas lainnya adalah mengerjakan LKS naik dari Siklus I menjadi $42 \%$ karena telah banyak siswa antusias dalam mengerjakan LKS. Aktivitas bertanya pada teman turun menjadi $14 \%$ dan aktivitas bertanya pada guru turun menjadi $12 \%$ berarti ketergantungan pada guru mulai menurun dan siswa sudah mulai mandiri. Prilaku yang tidak relevan turun menjadi 5\%. Hal ini terjadi pada beberapa siswa yang bergurau setelah selesai mengerjakan LKS sambil menunggu siswa lainnya selesai mengerjakan.

Data Hasil Belajar Siswa

Hasil belajar siswa diperoleh melalui tes yang diberikan setelah berakhirnya Siklus II sebagai Formatif II. Data hahsil belajar siswa dari Formatif II disajikan dalam Tabel 4.4.

Tabel 4.4 Distribusi Hasil Formatif

\begin{tabular}{|c|c|c|c|c|}
\hline \multicolumn{5}{|c|}{ II } \\
\hline Nilai & Frekuensi & $\begin{array}{l}\text { Rata- } \\
\text { Rata }\end{array}$ & $\begin{array}{l}\text { S. } \\
\text { Deviasi }\end{array}$ & $\begin{array}{l}\mathrm{K} \\
\text { Klasikal }\end{array}$ \\
\hline 60-69 & 4 & \multirow{6}{*}{87,34} & \multirow{6}{*}{12,78} & \multirow{6}{*}{$90,00 \%$} \\
\hline 70-79 & 8 & & & \\
\hline $80-89$ & 8 & & & \\
\hline $\begin{array}{l}90-99 \\
\end{array}$ & 4 & & & \\
\hline 100 & 16 & & & \\
\hline Jumlah & 40 & & & \\
\hline
\end{tabular}

Merujuk pada Tabel 4.4 diatas dapat dijelaskan bahwa dengan menerapkan model pembelajaran scramble diperoleh nilai rata-rata prestasi belajar siswa adalah 87,34, dengan KKM sebesar 75 maka ketuntasan belajar mencapai 90,00\% atau ada 36 siswa dari 40 siswa sudah tuntas belajar. Hasil tersebut 
menunjukkan bahwa pada siklus kedua secara klasikal siswa telah tuntas belajar, meski masih ada 4 siswa belum mencapai KKM. Karena siswa yang memperoleh nilai $\geq$ KKM hanya sebesar $85 \%$ atau mencapai kriteria ketuntasan dikehendaki yaitu sebesar 90\%. Sehingga dapat dikatakan Siklus II berhasil memberikan ketuntasan hasil belajar pada siswa.

\section{Refleksi}

Pada tahap ini akah dikaji apa yang telah terlaksana dengan baik maupun yang masih kurang baik dalam proses belajar mengajar dengan penerapan model Scramble melalui pembelajaran kooperatif pada Siklus II. Dari data-data yang telah diperoleh dapat duraikan sebagai berikut:

a) Selama proses belajar mengajar guru telah melaksanakan semua pembelajaran dengan baik. Meskipun ada beberapa aspek yang belum sempurna, tetapi persentase pelaksanaannya untuk masing-masing aspek cukup besar.

b) Berdasarkan data hasil pengamatan diketahui bahwa siswa aktif selama proses belajar berlangsung.

c) Kekurangan pada siklussiklus sebelumnya sudah mengalami perbaikan dan peningkatan sehingga menjadi lebih baik.

d) Aktivitas belajar siswa telah membaik dari Siklus I ke Siklus II, perbaikan aktivitas belajar siswa disajikan seperti gambar 4.1 berikut.

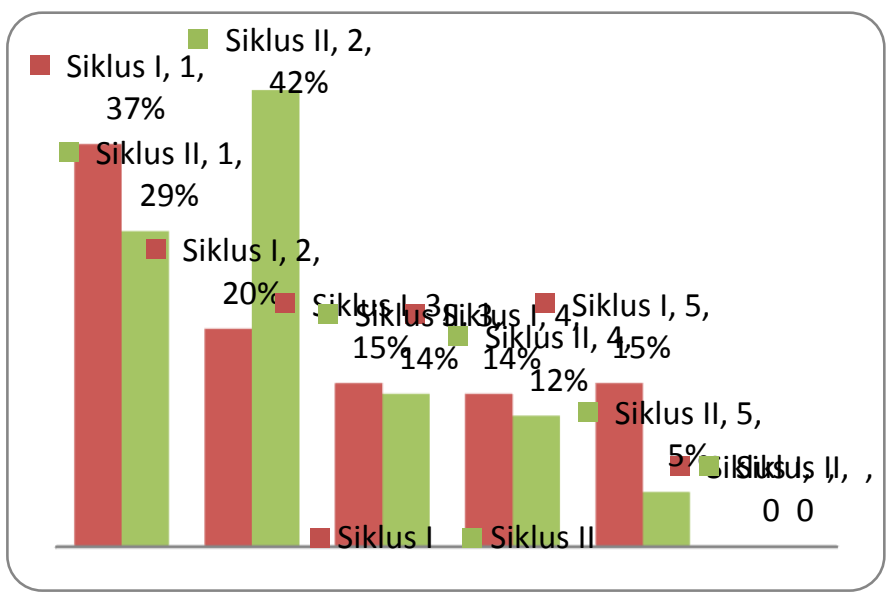

\section{Gambar 4.1 Grafik Aktivitas siswa Siklus I dan Siklus II}

Keterangan:

1. Menulis,membaca

2. Mengerjakan

3. Bertanya pada teman

4. Bertanya pada guru

5. Yang tidak relevan

e) Hasil belajar siswa pada Siklus II mengalami peningkatan dibandingkan Siklus I dan telah mencapai ketuntasan klasikal. Perbandingan hasil formatif I dan Formatif II disajikan dalam Gambar 4.2. 


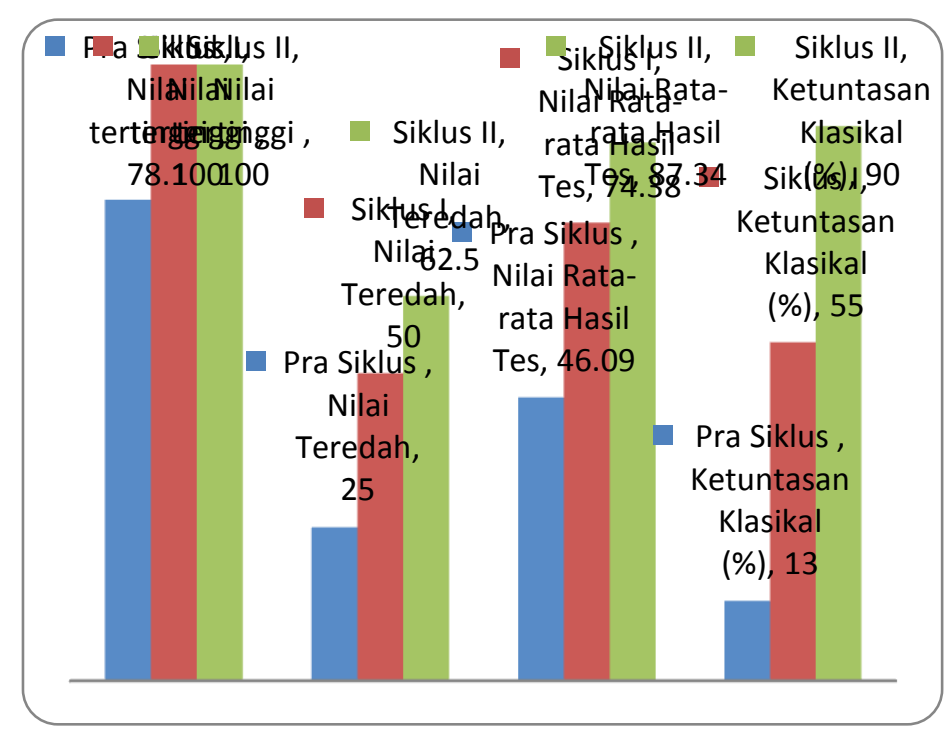

\section{Gambar 4.2 Grafik Hasil Belajar Kognitif}

Pada Siklus II guru telah menerapkan model pembelajaran scramble dengan baik dan dilihat dari aktivitas siswa serta hasil belajar siswa pelaksanaan proses belajar mengajar sudah berjalan dengan baik. Maka tidak diperlukan revisi terlalu banyak, tetapi yang perlu diperhatikan untuk tindakan selanjutnya adalah memaksimalkan dan mepertahankan apa yang telah ada dengan tujuan agar pada pelaksanaan proses belajar mengajar selanjutnya penerapan model pembelajaran Scramble dapat meningkatkan proses belajar mengajar sehingga tujuan pembelajaran dapat tercapai.

Karena telah terjawab rumusan masalah dalam penelitian dan keterbatasan kemampuan peneliti dalam hal waktu, biaya, serta kesesuian dengan perencanaan penelitian yang disusun sebelumnya dalam metodologi penelitian, maka penelitian dicukupkan samapai dua siklus.

\section{Pembahasan}

Merujuk pada Gambar 4.2. dapat dilihat bahwa nilai rata-rata sebelum penerapan model pembelajaran scramble yaitu berupa nilai pretes adalah 46,09 dengan ketuntasan belajar yang dicapai 13\%, setelah penerapan model pengajaran Scramble nilai siswa mengalami peningkatan. Berdasarkan hasil tes pada Siklus I, nilai rata-rata hasil belajar yang dicapai siswa adalah 74,38 dengan persentasi $55 \%$, untuk nilai rata-rata hasil belajar dan persentasi ketuntasan klasikal yang dicapai belum mencapai indikator keberhasilan yang ditetapkan karena masih banyak siswa memperoleh nilai yang di bawah kriteria ketuntasan minimum.

Setelah dilaksanakan Siklus II, maka hasil belajar siswa menurut Formatif II adalah rata-rata 87,34 dengan ketuntasan klasiklal mencapai $90 \%$. Karena nilai ratarata di atas KKM sebesar (75) dan ketuntasan klasikla telah mencapai $85 \%$. Maka tindakan Siklus II dapat dikatakan berhasil meningkatkan hasil belajar siswa samapai pada kriteria ketuntasan yang ditetapkan.

Merujuk pada Gambar 4.1, peningkatan kualitas aktivitas belajar ditunjukkan dengan perubahan aktivitas Siklus I ke Siklus II. Ratarata aktivitas menulis dan membaca mengalami perubahan dari proporsi $37 \%$ menjadi $29 \%$. Aktivitas 
mengerjakan dalam diskusi naik dari $20 \%$ menjadi 42\%. Aktivitas bertanya pada teman turun dari $15 \%$ menjadi $14 \%$. Aktivitas bertanya kepada guru turun dari $14 \%$ menjadi $12 \%$. Dan aktivitas yang tidak relevan dengan KBM turun dari $15 \%$ menjadi $5 \%$.

Nilai-nilai ini menunjukkan bahwa aktivitas siswa pada Siklus II lebih baik dari pada Siklus I, perubahan aktivitas individual seperti menulis dan membaca terjadi pada Siklus II, aktivitas kerja dalam kelompok mengalami kenaikan. Ketergantungan siswa pada guru menurun. ketergantungan positif antar siswa aktivitas bertanya sesama siswa turun sedikit. Kesimpulan ini diperkuat dengan temuan bahwa aktivitas yang tidak relevan dengan KBM pada Siklus II menyusut jauh dari Siklus I.

Kegagalan mencapai ketuntasan belajar pada Siklus I, diakibatkan beberapa kekurangan, yaitu:

a. Guru kurang maksimal dalam memotivasi siswa dan dalam menyampaikan tujuan pembelajaran

b. Siswa belum focus melaksanakan diskusi karena banyak yang bingung dan tidak ada pemikiran untuk didiskusikan.

c. Pemanfaatan LKS yang belum begitu optimal dalam mengarahkan aktivitas belajar siswa. d. Beberapa siswa belum memahami peran dan tugasnya dalam bekerja kelompok karena belum terbiasa dengan model pembelajaran yang diterapkan hal ini menyebabkan muculnya aktivitas individual menulis dan membaca (37\%) sebagai akibat siswa tidak mengerti apa yang harus dikerjakan.

e. Interaksi antar siswa belum berjalan dengan baik karena siswa belum terbiasa untuk menyampaikan pendapatnya kepada sesama teman lainnya dalam menyelesaikan masalah.

f. Adanya siswa yang pasif dan menggantungkan

permasalahan yang dihadapi kepada kelompoknya mengakibatkan aktivitas kinerja belum optimal (20\%).

g. Dalam diskusi kelompok hanya didominasi oleh beberapa siswa yang lebih mampu/pandai saja terlihat aktivitas tidak relevan oleh beberapa siswa (15\%) dan dari dokumentasi penelitian

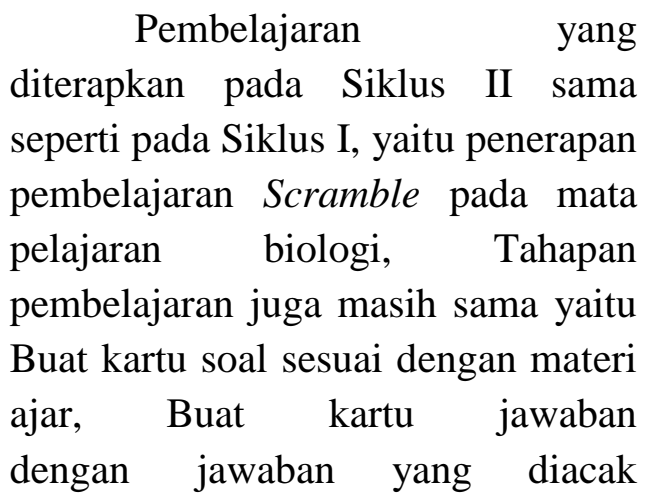


hurufnya, Guru menyajikan materi sesuai kompetensi yang ingin dicapai dan Guru membagikan kartu soal dan kartu jawaban kepada siswa.

Selama pengamatan terhadap kegiatan siswa Siklus II (aktivitas siswa), penilaian terhadap tes hasil belajar (ranah kognitif), dan dokumentasi terhadap pelaksanaan penerapan pembelajaran kolaboratif Siklus II, meski masih terlihat hal-hal yang harus diadakan perbaikan, namun secara keseluruhan tahapan pembelaajaran sudah berlangsung cukup baik. Kerena keterbatasan waktu dan biaya maka penelitian ini direncanakan dalaam dua siklus saja. Hasil belajar siswa sudah menunjukkan peningkatan dan semua siswa dikatakan tuntas. Secara keseluruhan semua aspek dalam hasil belajar mengalami peningkatan dari Siklus I ke Siklus II. Karena proses pelaksanaan pada Siklus I dan Siklus II telah dapat mencapai hasil dari pembelajaran yang diharapkan dan telah dapat menjawab rumusan masalah pada penelitian ini, maka tidak diadakan Siklus selanjutnya.

\section{SIMPULAN DAN SARAN}

\section{Simpulan}

Adapun kesimpulan dari penerapan model pembelajaran Scramble selama kegiatan belajar mengajar pada materi pokok teori tentang asal usul kehidupan di kelas XII IPA3 SMA Negeri 1 Panyabungan sebagai berikut: a. Data aktivitas siswa menurut pengamatan pengamat pada Siklus I antara lain: menulis/membaca (37\%), bekerja (20\%), bertanya sesama teman (15\%), bertanya kepada guru (14\%), dan yang tidak relevan dengan KBM (15\%). Data aktivitas siswa menurut pengamatan pada Siklus II antara lain menulis/membaca (29\%), bekerja (42\%), bertanya sesama teman $(14,0 \%)$, bertanya kepada guru (12\%), dan yang tidak relevan dengan KBM (5\%). Terjadi peningkatan aktivitas belajar biologi siswa saat menerapkan model pembelajaran scramble.

b. Terjadi peningkatan hasil belajar siswa setelah menerapkan Model Pembelajaran scramble pada Formatif I dan Formatif II menunjukkan nilai rata-rata 74,38 dan 87,34 serta ketuntasan individu 22 siswa dan 36 siswa dan ketuntasan kelas adalah 55\% dan $90 \%$ dari data tersebut menunjukkan tuntas kelas sesuai dengan KKM Biologi.

\section{Saran}

Setelah melakukan kegiatan belajar mengajar pada tahap Siklus I, dan Siklus II maka diperoleh datadata kemudian data tersebut di analisis dan juga hasil rekaman peneliti selama KBM maka perlu saran agar pengguna atau yang memanfaatkan Model Pembelajaran Scramble Selama Kegiatan Belajar 
di sekolah benar-benar bermanfaat sesuai dengan tujuan penelitian.

a. Dalam upaya meningkatkan kualitas proses pembelajaran pada mata pelajaran Biologi, guru SMA menerapkan model-model pembelajaran yang aktif, kreatif, inovatif, efektif dan menyenangkan.

b. Model Scramble masih banyak kekurangannya untuk itu para guru SMA harus bisa membuat lebih bervariasi dan inovatif untuk mendorong motivasi siswa dan kemampuannya yang berbeda-beda.

c. Dalam Mata Pelajaran Biologi guru hendaknya berkreasi dalam memanfaatnya media pembelajaran yang menunjang efektifitas kegiatan pembelajaran Biologi.

\section{DAFTAR RUJUKAN}

Aqib, Z., (2006), Peneltian

Tindakan Kelas. Penerbit, Yrama Widya, Bandung.

Arikunto, Suharsimi. 2002. Prosedur

$\begin{array}{lr}\text { Penelitian } & \text { Suatu } \\ \text { Pendekatan } & \text { Praktek. } \\ \text { Jakarta: } & \text { Rineksa } \\ \text { Cipta. } & \end{array}$

Aryulina, D, dkk. 2008. Biologi SMA

dan MA Untuk Kelas

XI. Jakarta :

Yudhistira

Azhar, Lalu Muhammad. 1993. Proses Belajar

Mengajar Pendidikan.

Jakarta: Usaha

Nasional

Bahri Djamarah dan Aswan Zain, 2006. Strategi Belajar Mengajar. Jakarta: PT Rineka Cipta.

Djamarah, Syaiful Bahri. 2002.

Strategi Belajar

Mengajar. Jakarta:

Rineksa Cipta.

Hamalik. 1991, Perencanaan dan Manajemen

Pendidikan, Bandung

: CV Mandar Maju.

Mulyasa. 2003, Kurikulum Berbasis

Kompetensi, Konsep,

Karakteristik dan

Implementasi,

Bandung, PT. Remaja

Rosdakarya. .2003, Manajemen

Berbasis Sekolah, Konsep, Strategi, dan Implementasi, Bandung : PT. Remaja

Rosdakarya. 